Семененко O.М., д-р військ. наук, ст. наук. співроб. ${ }^{1}$ Васюхно C. I. ${ }^{2}$

(0000-0001-6477-3414); Бокій В. Г. ${ }^{3}$ (0000-0002-0884-0405); Бутенко М. П.2

1 - Центральний науково-дослідний інститут Збройних Сил України, Київ; (0000-0001-7272-5826)

2 - Центр воєнно-стратегічних досліджень Національного університету оборони України імені Івана Черняховського, м. Київ;

3 - Генеральний штаб Збройних Сил України

\title{
Методичний підхід до прогнозування динаміки розвитку Збройних Сил України з урахуванням достатності та ефективності освосння виділених фінансових ресурсів
}

Резюме. Однією з важливих проблем сучасного воєнного будівництва є правильне прогнозування розвитку Збройних Сил України. У статті розглядаються питання підвищення ефективності прогнозування розвитку Збройних Сил України та обгрунтованості формування потреб щодо частки державного бюджету України в інтересах Збройних Сил за допомогою урахування під час прогнозування показників достатності їх фінансового забезпечення та ефективності освоєння виділених фінансових ресурсів.

Ключові слова: воєнне будівництво; система; прогнозування; достатність фінансування; ефективність освоєння коштів; потреба у фінансових ресурсах; рівень інфляції; оцінювання рівня розвитку Збройних Сил України.

Постановка проблеми. У Збройних Силах (ЗС) України продовжується робота щодо запровадження ефективного оборонного планування та управління оборонними ресурсами. Алгоритм оборонного планування розвитку 3С України крок за кроком використовує результати аналізу досвіду провідних країн світу, які перейшли від планування у галузі оборони на основі загроз, до оборонного планування, орієнтованого на досягнення військами (силами) спроможностей, необхідних для виконання покладених на них завдань [1-4]. На сьогодні планування орієнтоване на спроможності $\epsilon$ стандартною процедурою для планування розвитку національних збройних сил та невід'ємною складовою трансформаційних процесів у країнах НАТО [5].

Процедура прийняття рішень військовополітичним керівництвом держави 3 питань будівництва і розвитку Збройних Сил - процес багатоаспектний iз значною кількістю невизначеностей. Особливого значення набуває процедура прогнозування. Цікавість до майбутнього виходить безпосередньо 3 потреби сьогодення. Передбачення подій дає змогу завчасно приготуватись до них, мінімізувати ризики, врахувати позитивні та негативні наслідки, а за необхідністю втрутитись у процес розвитку та внести корективи.

Оскільки в сучасних умовах суттєво ускладнилися цілі соціально-економічного розвитку та їх співвідношення 3 фінансовими

структурами, тривають зміни у фінансовому потенціалі держави за джерелами, структурою i динамікою. Це потрубує нових підходів i методологічних рішень під час фінансового прогнозування і планування [6].

Одним iз принципових питань фінансово-економічного прогнозування у військовій справі $\epsilon$ визначення опорних (оптимальних) тенденцій зміни фінансовоекономічних параметрів (включаючи вартісні показники) видаткової частини бюджетних коштів, що виділяються на військове будівництво і реалізацію визначених програм розвитку 3С. Прогнозування є першою стадією планування. Після прогнозування проводиться перспективне (довгострокове) планування, далі середньострокове, поточне та оперативнокалендарне планування. Етапи планування мають бути орієнтовані не тільки у часі, але й у площинах функціонального та територіального поділу об'єкта планування (ЗС України). Це створює передумови для розроблення методичного підходу щодо прогнозування (розподілу) фінансових ресурсів 3 урахуванням ефективності їх освоєння.

Аналіз останніх досліджень, публікацій. Прогнозування i планування бюджету постійно перебувають у полі зору науковців. У теорію бюджетних відносин значний внесок зробили такі відомі вчені, як А. Вагнер, Дж. Гелбрейт, Дж.М. Кейнс, Ф. Нітті, П. Самуельсон, Дж. Стігліц та інші. Найвідоміші праці з військової проблематики 
- роботи Г. Канна "Про термоядерну війну" (1960), “Роздуми про неможливе" (1965), "Про ескалацію” (1966), “Рік 2000” (1967), “Як перемогти в сучасній війні" (2004).

Серед вітчизняних досягнень виділимо наукові праці А. Даниленка, Ю. Пасічника, О. Сунцової, Т. Єфименко, І. Чугунова та інших. Українські науковці дають різні визначення понять “прогнозування" i “планування " в бюджетному процесі, оскільки чіткого законодавчого тлумачення цих категорій немає $\mathrm{i}$ в Бюджетному кодексі України.

У своїй роботі Ю. Пасічник під бюджетним прогнозуванням розуміє визначення основних показників бюджету на перспективу. Він вважає, що бюджетне планування - це процес формування показників бюджетного змісту державними законодавчими та виконавчими органами певного рівня на конкретний період часу [7]. Деякі вчені вважають, що бюджетне прогнозування $\epsilon$ науково обгрунтованим передбаченням напрямів розвитку бюджетної системи та іï можливого стану в майбутньому, альтернативних шляхів іiі формування, а також строків досягнення певних визначених параметрів бюджетного розвитку. На відміну від бюджетного прогнозування, бюджетне планування передбачає встановлення чітких бюджетних цілей і шляхів їх досягнення, певних бюджетних показників [8].

О. Василик вживає термін “фінансове планування і прогнозування”, де планування - це науково обгрунтований процес визначення джерел створення i напрямів використання фінансових ресурсів в економіці держави для забезпечення стабільного економічного i соціального розвитку [6]. Автор не встановлює чіткої межі між поняттями “планування" i “прогнозування", наголошуючи, що фінансове планування і прогнозування стають важливим елементом державного регулювання економічних i соціальних процесів. За їх допомогою активізуються фінансові підойми та стимули, забезпечується мобілізація i раціональне направлення коштів на загальнодержавні потреби [6]. За висловлюванням відомих учених, прогноз за своєю природою має альтернативний, варіантний зміст. У цьому розумінні прогнозування являє собою дослідницьку базу планування, що має, проте, власні методологічні та методичні засади, багато в чому відмінні від планування. Розроблення прогнозів грунтується на прогностичних методах, натомість планування спирається на більш чіткі й точні методи нормативних, балансових та інших розрахунків. Головна відмінна риса планування визначеність i директивність завдань. Отже, передбачення набирає у плані найбільшої конкретності та визначеності. Зрозуміло, що різниця між прогнозуванням і плануванням у бюджетному процесі полягає в тому, що прогнозування дає змогу бачити ціль у далекій перспективі, включаючи можливі фактори ризиків i впливу. Планування ж $\epsilon$ тією реальністю, яку ми бачимо перед собою, більш конкретним i передбачуваним явищем. Якщо прогноз - деякий імовірнісний характер дій, то планування - уже прийняте рішення, яке наближає нас до відповідної мети.

У період, на який затверджується план або програма, можуть розроблятися тільки прогнози виконання плану (програми), які призначені для цілей періодичного коригування планів, програм через зміни впливів різних факторів (потреб, технічних або економічних можливостей, економічної доцільності тощо). У теоретичному плані прогноз $є$ частиною пізнання майбутнього розвитку економічних процесів і керівництвом для прийняття виважених управлінських рішень. Прогнозування це процес, унаслідок якого отримуємо імовірнісні дані про майбутній стан об'єкта. Помилки i прорахунки прогнозу впливають на його якість $\mathrm{i}$ результативність планування. Необхідність поглиблення досліджень і розроблення нових форм і методів обгрунтованого прогнозування в бюджетному процесі продиктована важливістю підвищення ефективності та результативності бюджетних видатків 3 метою досягнення перспективних завдань економічного та соціального розвитку України. Прогнозування та планування розвитку складних систем державного значення, таких як ЗС України, передбачає, що для отримання інформації про перспективи їх розвитку, треба визначити причини й основні рухомі сили їх розвитку та розробити адекватні умовам прогнозування методи реалізації цих процесів це $\mathrm{i} \in$ основними завданням планування та прогнозування.

Отже питання пошуку методів прогнозування фінансових ресурсів, взаємозв'язку показників розвитку системи (ЗС України) 3 показниками динаміки обсягів імовірно виділених ресурсів є досить важливими та актуальним завданнями функціонування системи оборонного планування в Україні [1-10].

Метою статті є удосконалення методичного підходу до прогнозування динаміки розвитку Збройних Сил України з урахуванням достатності та ефективності освоєння виділених фінансових ресурсів.

Виклад основних положень матеріалу статті. Для забезпечення створення, зміцнення i розвитку ЗС України, підвищення їх готовності до виконання завдань за призначенням та участі у проведенні спільних бойових дій 3 підрозділами НАTO мають відбутися кардинальні зміни системи прийняття управлінських рішень, яка потребуватиме 
запровадження сучасних інструментів фінансового управління. Вихідним елементом управління фінансовими ресурсами $\epsilon$ прогнозування та планування, які дають змогу обгрунтувати оптимальну потребу в коштах 3 урахуванням ефективності їх освоєння.
Планування розвитку ЗС України як елемент управління $\epsilon$ інформаційним процесом. Особливість цього процесу полягає в наявності часових інтервалів зсуву інформації входу відносно інформації виходу (рис. 1).

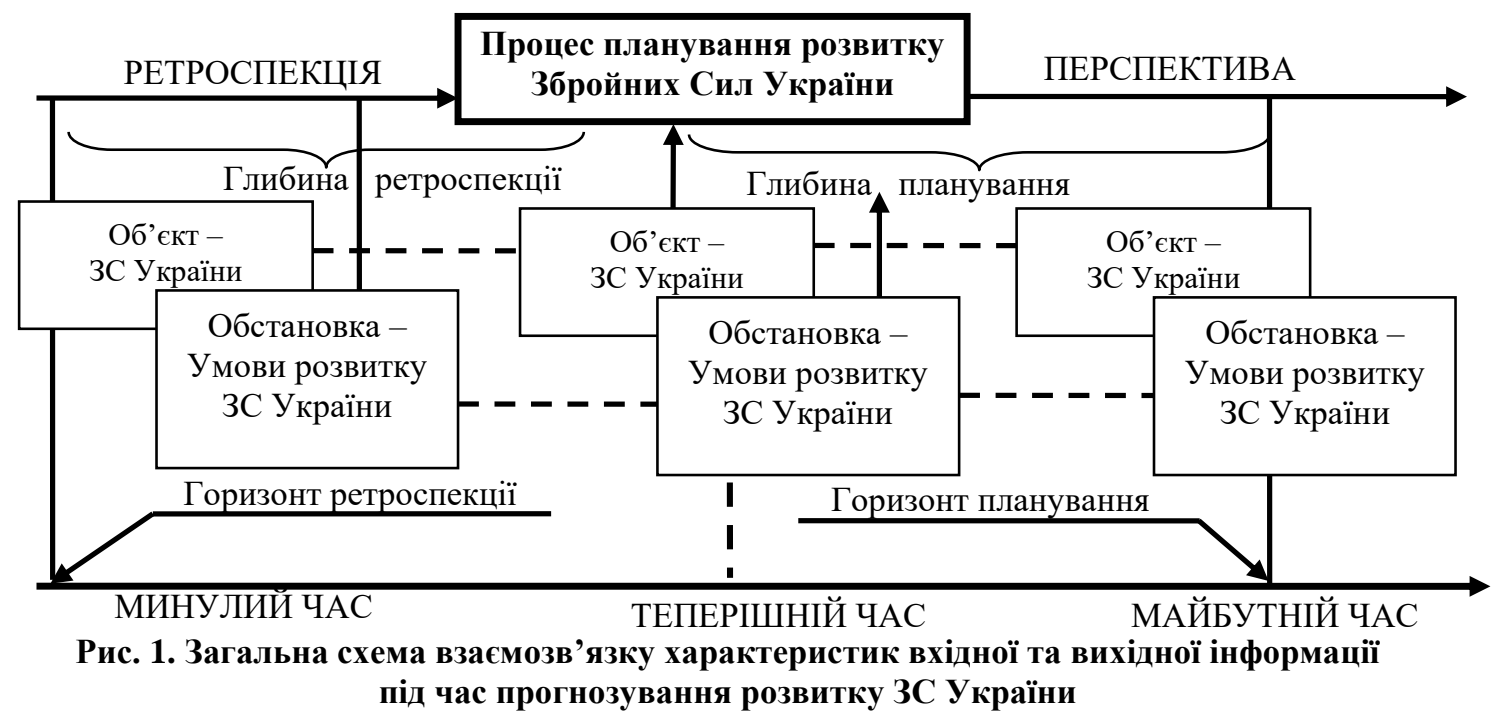

Під час планування розвитку ЗС України вхідними $\epsilon$ потоки інформації щодо минулого (ретроспективна інформація: стан розвитку ЗС України, результати виконання планів i програм розвитку за минулий період, динаміки впливу різних факторів за минулий період, що аналізується). Вихідними потоками інформації $\epsilon$ потоки про майбутнє на перспективу (очікувані результати змін стану розвитку ЗС України, очікувані результати виконання програм розвитку ЗС України). Під час аналізу вихідних потоків інформації для прийняття рішень (на стадії формування (коригування) програм, планів) використовується також інформація про стан об'єкта розвитку та обстановки в момент розроблення плану або програми. На підставі аналізу ретроспективної інформації можна спрогнозувати потреби ЗС України у фінансових ресурсів та очікувані показники розвитку ЗС України на визначений для прогнозування період.

Задачу планування розвитку ЗС України на середньо- та довгострокову перспективу можна поділити на два взаємопов'язані напрями: перший - це формування функції оптимальної зміни керованих фінансово-економічних параметрів розвитку на основі прогнозних оцінок динаміки зміни некерованих параметрів внутрішнього стану розвитку ЗС України i динаміки зміни параметрів соціальноекономічного розвитку країни загалом; другий оцінювання вірогідності характеристик і точності прогнозів динаміки економічних параметрів стану зовнішнього й внутрішнього середовища розвитку ЗС України [10].

Один 3 найрозповсюдженіших методів прогнозування $є$ метод екстраполяції, тобто у продовженні в майбутнє тенденцій, які відбувались у минулому [11]. Екстраполяція тенденцій динамічних рядів широко застосовується через іiі простоту та можливість здійснення обробки невеликої кількості інформації. Екстраполяція базується на таких припущеннях: розвиток об'єкта може бути охарактеризований плавною траєкторією трендом; загальні умови, що визначали тенденцію розвитку в минулому не зміняться істотно в майбутньому.

Фактор часу визначає низку специфічних особливостей процесу та результатів двох стадій планування: прогнозування та розроблення плану. Цей фактор $\epsilon$ первинним під час розмежування понять прогнозування та планування (розроблення планів). Він визначає границі процесів планування та прогнозування.

Прогноз розвитку ЗС України розробляється для цілей розроблення плану або програми на строк, який більший планового періоду, та після затвердження плану або програми втрачає своє самостійне значення. Прогнозування і складання планів, програм $\epsilon$ елементами єдиної системи планування, які мають поєднуватись спільністю цілей та завдань. Як основні рухомі сили розвитку ЗС України $\epsilon$ потреби щодо рівня захищеності держави на плановий період, технічні можливості та економічна доцільність. Отже до основних задач планування та прогнозування розвитку ЗС України можна віднести: визначення та встановлення основних цілей розвитку $3 \mathrm{C}$ України; пошук оптимальних шляхів і засобів їх досягнення; визначення ресурсів, необхідних для 
реалізації поставлених (чітко сформульованих) цілей.

Вибір цілей $є$ результатом аналізу завдань, які необхідно вирішувати ЗС України протягом планового періоду. Шляхи і засоби досягнення цілей визначаються на основі аналізу ретроспективної інформації щодо розвитку ЗС України та науково-технічного прогресу. Вибір цілей $\mathrm{i}$ засобів для їх досягнення мають поєднуватися 3 визначенням потреб у ресурсах. Під час визначення ресурсних потреб потрібно співставляти планові та прогнозовані показники ресурсів (фінансових, людських, матеріальних). Оцінюванню підлягають як потрібні ресурси, так й імовірні обмеження їх величини у діапазоні часу упередження плану або прогнозу [4-15]. Достовірність та коректність отриманих оцінок прогнозування планується підвищити завдяки урахуванню у процесі прогнозування розвитку 3С України показників достатності їх фінансування за минулий період та ефективності освоєння коштів під час виконання програм i планів розвитку. Показник достатності фінансування ЗС України $\epsilon$ показником перспективної інформації, а показник освоєння виділених ресурсів буде показником ретроспективної інформації. Поєднання цих показників єдиними математичними моделями дадуть змогу прогнозувати динаміку рівня розвитку ЗС України за різними горизонтами планування залежно від прогнозованих обсягів задоволення потреб ЗС України фінансовими ресурсами.

Під час прогнозування динаміки рівня розвитку ЗС України першим етапом методичного підходу є формування бази даних показників ретроспективної інформації до яких належать: $W_{t \Pi}^{\text {факт }}, \quad W_{t \Pi}^{\text {план }}-$ фактичні та планові результати виконання ефективності виконання програм розвитку за минулі п'ять років $(t \in(t, t-5)$, де $t-$ порядковий номер року в програмі); $\quad C_{t \Pi}^{\text {факт }}, \quad C_{t \Pi}^{\text {план }}-$ фактичні та планові показники фінансування програми розвитку ЗС України за минулі п'ять років. На основі цих показників розраховуються середня ефективність виконання програми за попередні $t$ 5 роки $\bar{W}_{t \Pi}=\sum_{t}^{t=5}\left(W_{t \Pi}^{\text {факт }} / W_{t \Pi}^{\text {план }}\right) / 5$ та середня ефективність фінансування програм розвитку 3С за попередні $t-5 \quad$ роки $\bar{C}_{t \Pi}=\sum_{t}^{t=5}\left(C_{t \Pi}^{\text {факт }} / C_{t \Pi}^{\text {nлан }}\right) / 5$, а також середній показник достатності фінансування діючої

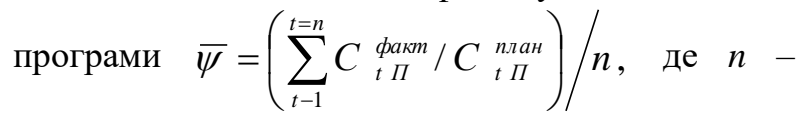
кількість років програми, що минули. Також до основних розрахункових

показників ретроспективної інформації належить середній показник рівня інфляції за минулих п'ять років $\bar{\varepsilon}_{t \Pi}=\sum_{t}^{t-5} \varepsilon_{t I \Pi} / 5$.

До основних показників перспективної інформації під час прогнозування розвитку ЗС України відносяться: $W_{\text {потр }}$ - очікуваний ефект зміни рівня розвитку ЗС України від реалізації заходів програми розвитку (П); $\Delta W_{\text {потр }}$ - планова динаміка рівня розвитку ЗС України за роками програми; $W_{0}$ - рівень розвитку 3С України на початку дії програми та на $t$-й рік оцінювання; $C_{t \text { nс }}^{\text {nотр }}$ - потреба фінансування дії програми розвитку за роками; діапазон можливого фінансування програми розвитку ЗС України за роками (\% ВВП, млн грн) $C_{\sum \text { мож }}^{t}=f(B В \Pi), C_{\sum \text { мож }}^{t} \in\left(C_{\sum \text { можс }}^{t \text { min }} ; C_{\sum \text { мож }}^{t \max }\right)$.

На основі отриманих вихідних даних розраховуються проміжні показники для прогнозування. До основних показників цього етапу відносяться: показник планової динаміки рівня розвитку 3С України за роками програми $\left(\Delta w_{t}^{\text {nomp }}\right), \quad$ а також очікуваний ефект від реалізації програми розвитку ЗС України, тобто плановий показник очікуваного результату зростання рівня розвитку ЗС України $\left(W_{T}^{\text {nomp }}\right)$; прогнозований показник фактичного рівня фінансування програми розвитку в $t$-й рік програми $\left(\Delta c_{t}^{\text {факm }}\right) ; \quad$ середній показник ефективності освоєння коштів на заходи програм розвитку ЗС України за останні п'ять років станом на $t$-й рік програми:

$$
\lambda_{\mathrm{t}}=\frac{\bar{W}_{t \Pi}}{\bar{C}_{t \Pi}} .
$$

Далі необхідні процедури уточнення показника необхідного приросту рівня розвитку ЗС України $\Delta w_{t \text { зС }}^{\text {потреба }}=w_{t \text { зС }}^{\text {потреба }}-w_{t-1 \text { ЗС }}^{\text {факт }}$ та уточнення визначеної для цього потреби у фінансових ресурсах на $t$-й рік програми. Величина потреби $є$ функцією від необхідного приросту рівня розвитку 3 С України станом на $t$ й рік програми: $C_{t 3 C}^{\text {потреба }}=f\left(\Delta w_{t \text { зС }}^{\text {потреба }}\right)$.

Наступним кроком запропонованого методичного підходу $\epsilon$ формування та вибір функціональної залежності для опису процесу визначення приросту рівня розвитку ЗС України залежно від показника можливого обсягу фінансування їх у $t$-му році (рис. 2 , рис. 3 ). Діапазон можливого фінансування розвитку ЗС України в $t$-му році розглядається від мінімально до максимально можливого. У загальному вигляді запропонована функціональна залежність 
$\epsilon$ степеневою функцією зі змінною $C_{t}^{3 C}$, яка характеризує можливий рівень фінансування 3С України в $t$-му році, у якості степеня використовується середній показник ефективності освоєння коштів $\lambda_{\mathrm{t}}$, який після

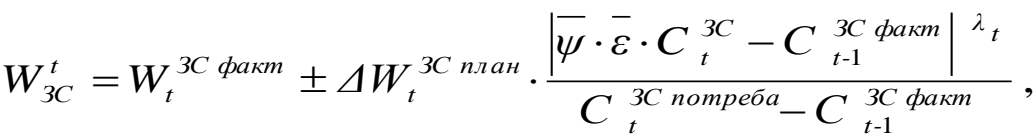

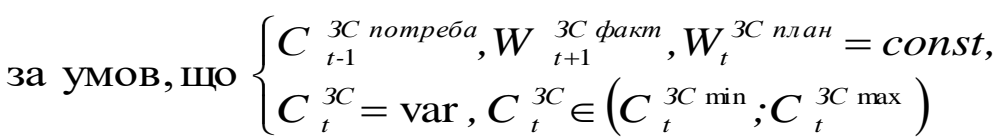

Відповідно до визначеної функціональної залежності $\epsilon$ три варіанта розв'язання задачі (відносно розрахованої критичної точки (рис. 2, рис. 3.)), тобто за умови, якщо рівень фінансування потреб ЗС України в $t$-му році нижче за рівень фінансування минулого $t-1$-го року 3 урахуванням середніх показників рівня достатності фінансування програми $\psi_{\text {t дпр та }}$ рівня інфляції $\bar{\varepsilon}_{\mathrm{t} \text { дпр }}$ протягом останніх п’яти

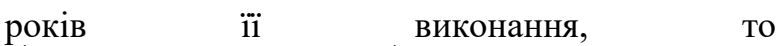
$\left(\bar{\psi} \cdot \bar{\varepsilon} \cdot C_{t}^{3 C}-C_{t-1}^{3 C}\right.$ факт $) \leq 0$, тоді відбувається процес спадання рівня розвитку ЗС України замість спланованого його нарощування, i функція має визначатися як (рис. 2):

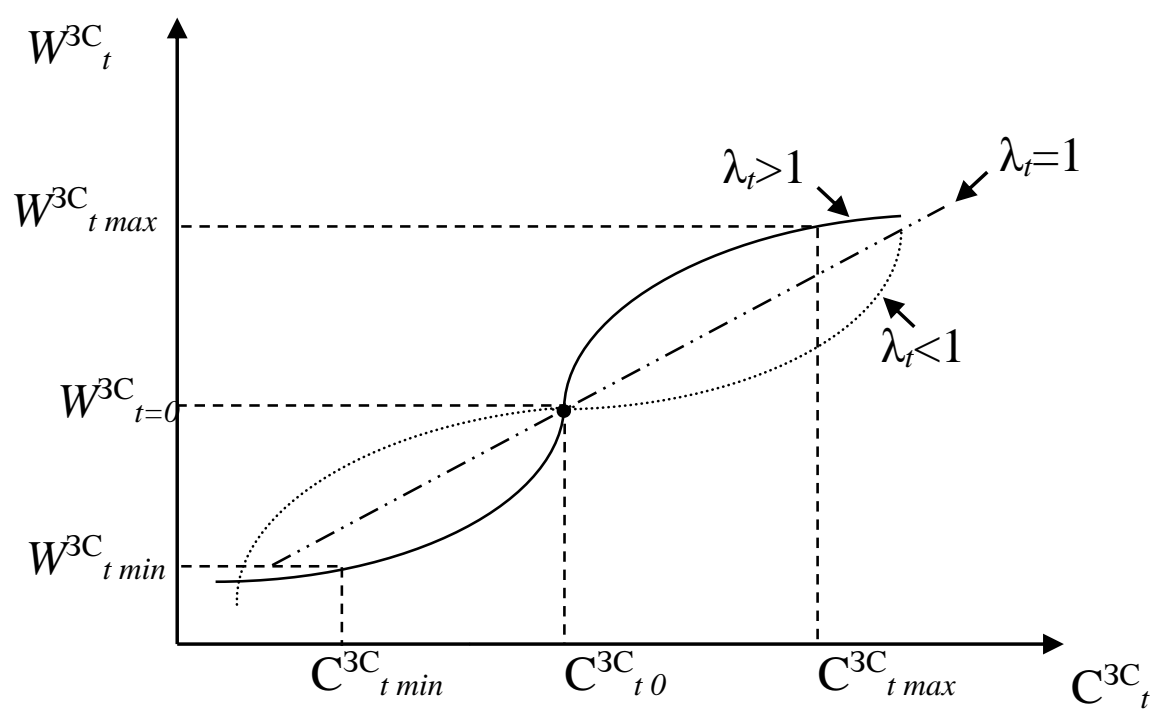

Рис. 2. Функціональна залежність динамки рівня розвитку ЗС України від рівня їх фінансування за різних показників ефективності освосння фінансових ресурсів

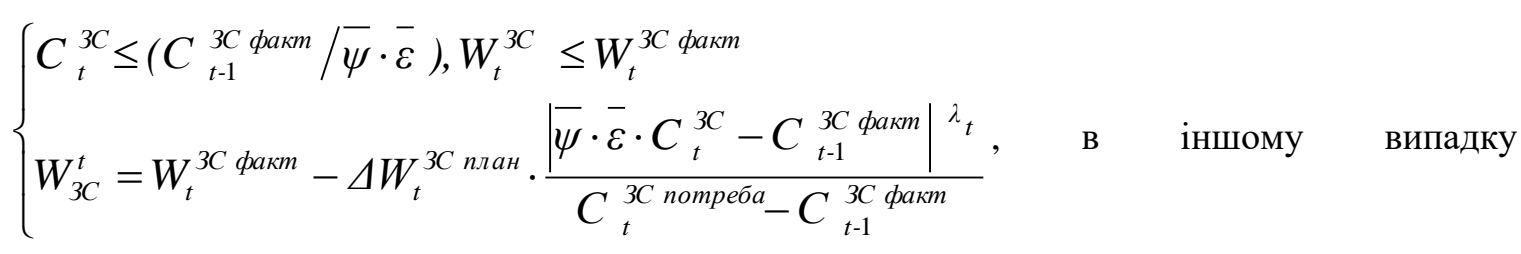

відбувається процес зростання рівня розвитку та функціональна залежність визначається як (рис. 2):

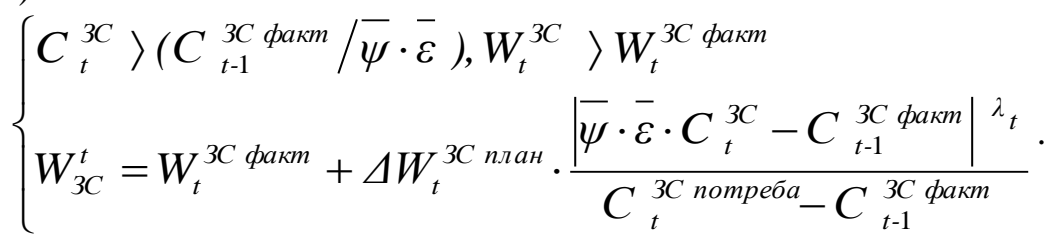

Швидкість зростання або спадання рівня розвитку ЗС України залежить від запланованих обсягів його зростання $\left(\Delta w_{t}^{\text {план }}\right)$ та від середнього показника ефективності освоєння виділених фінансових ресурсів за останні п'ять років виконання програм станом на $t$-й рік $\left(\lambda_{\mathrm{t}}\right)$ (рис. 2). 
У функціональних залежностях зміни рівня розвитку ЗС України від рівня їх фінансування за різних показників ефективності освоєння бюджетних коштів станом на $t$-й рік дії програми:

$$
\text { при } \lambda_{t}<1 \quad \max \left(\frac{\Delta W}{\Delta C}\right) \Rightarrow n p u C_{t}^{3 C} \rightarrow C_{t o p t}^{3 C}
$$

необхідна оптимізація за максимального відношення приросту рівня розвитку ЗС України відносно приросту рівня фінансування;

$$
\max \left(\frac{\Delta W}{\Delta C}\right) \Rightarrow n \text { за } C_{t}^{3 C} \rightarrow C_{t \max }^{3 C}, \quad \text { якщо } \quad \begin{array}{ll}
\lambda_{t} \geq 1 \\
\text { тобто }
\end{array}
$$

$$
\max W_{t}^{3 C} \Rightarrow C_{t \max }^{3 C} \text { оптимальне }
$$

значення

приросту рівня розвитку знаходиться на кінцях проміжку можливого рівня фінансування.

$$
\text { Результатами оцінювання буде }
$$

прогнозована динаміка рівня розвитку ЗС України залежно від рівня їх фінансування [15]. На рис. 3 відображені графічні види отриманих досліджуваних функціональних залежностей за різних показників ефективності освоєння коштів.

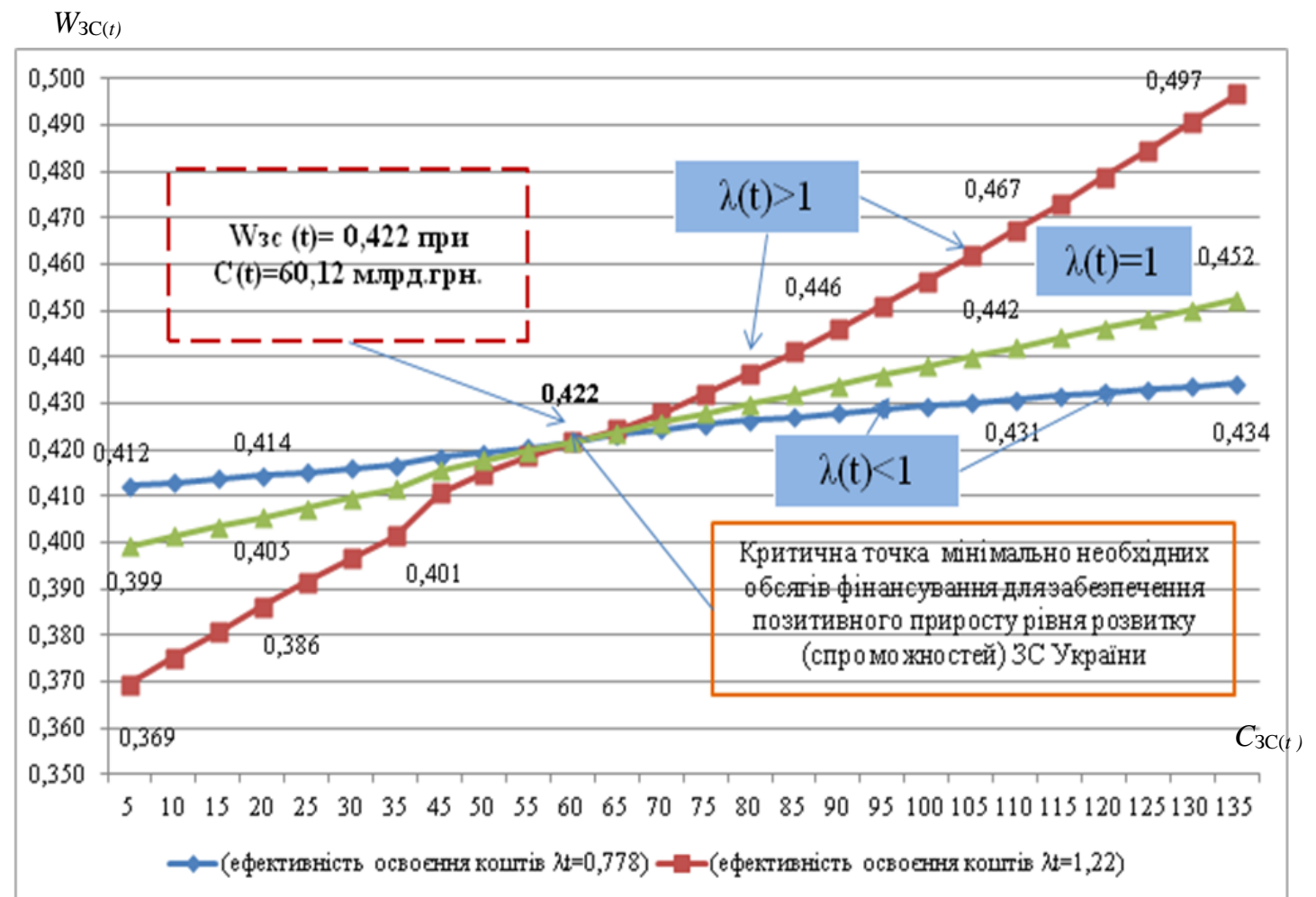

Рис. 3. Функціональні залежності динаміки рівня розвитку ЗС України від рівня їх фінансування за різних показників ефективності освосння фінансових ресурсів

За визначеними функціональними залежностями після проведення оцінювання економічних прогнозованих можливостей держави щодо рівня забезпечення ЗС України, відповідно до визначеного прогнозу можна оцінити вплив прогнозних економічних можливостей держави на перспективні спроможності ЗС України. Поєднання цих оцінок за термінами виконання програми розвитку 3С України, дасть змогу сформувати динаміку розвитку 3С України. Застосування представленого методичного підходу дасть змогу підвищити ефективність планування розвитку 3С України та обгрунтованість очікуваних результатів програм розвитку.

\section{Висновок та напрям подальших} досліджень. Запропонований підхід до прогнозування динаміки розвитку ЗС України 3 урахуванням достатності та ефективності освоєння виділених фінансових ресурсів дасть змогу коректніше прогнозувати та коригувати динаміку розвитку 3С України під час формування програм розвитку 3С України на середньо- та довгострокову перспективу, а також обгрунтованіше підходити до розв'язання питань визначення потреб ЗС України в цих програмах.

\section{СПИСОК ВИКОРИСТАНОЇ ЛІТЕРАТУРИ}

1. Світова гібридна війна: український фронт : монографія / за ред. В. П. Горбуліна. К.: НІСД, 2017. $496 \mathrm{c}$.

2. Марко И. Ю Финансирование развития вооружений и военной техники в 2012 году будет увеличено. Мы начнем интенсивную боевую подготовку всех видов 
войск - директор финдепартамента Минобороны. URL: http://ak-inzt.net/ ukrarmy/520-27-09-2011.

3. Основні оборонні аспекти доповіді Президента України. URL: http://www.ukrgold.net/links/21951/21961/.

4. Методика розрахунків обсягів лімітів вилучення техніки національної економіки для забезпечення потреб ЗС України в особливий період. К. : ЦНДІ ЗС України., 2009. 45 с.

5. Сучасні особливості впровадження методу планування на основі спроможностей у систему оборонного планування в Збройних Силах України / Р. В. Бойко, С. С. Масловський, О. М. Семененко та ін. Збірник наукових праць Харківського начіонального університету Повітряних Сил Украӥни. 2017. № 5 (54). C. $187-197$.

6. Василик О. Д. Теорія фінансів : підруч. К. : НІОС, 2003. $416 \mathrm{c}$.

7. Пасічник Ю. В. Бюджетна система України : навч. посіб. К. : Знання, 2008. 670 с.

8. Фінанси України: інституційні перетворення та напрями розвитку ; за ред. І.Я. Чугунова. К. : ДННУ АФУ, 2009. $848 \mathrm{c.}$

9. Система підтримки прийняття рішення “Оцінювання рівня оперативних спроможностей Збройних Сил України в залежності від їх рівня фінансування" (версія

Стаття надійшла до редакції 10.06.2019
$3.1)$; ч. 1-4., Київ : НУОУ імені Івана Черняховського, 2016. $264 \mathrm{c}$.

10. Бойко Р. В., Леонов В. В., Вавилова Н. В., Таврин В. А., Пташник В. М. Достовірність фінансовоекономічних прогнозів у воєнному будівництві. Збірник наукових праиь Системи обробки інформаиії. 2014. Вип. № 6 (124). С. 180-186.

11. Четыркин Е. М. Статистические методы прогнозирования. Москва : Статистика, 1975. 184 с.

12. Викулов С. Ф. Военно-экономический анализ. Ярославль : ЯВФЄА, 2011.

13. Динаміка ВВП України. Прогноз номінального та реального ВВП. (2017-2018 pp.). URL: http://index.minfin.com.ua/index/gdp/.

14. Про розподіл коштів, передбачених у Державному бюджеті на 2017 рік. Особливості розподілу на 02.2017 року. URL: zakon.rada.gov.ua/laws/show/81-2017-p.

15. Метод прогнозування динаміки розвитку спроможностей Збройних Сил України з урахуванням ефективності освоєння фінансових ресурсів / Р. В. Бойко, С. С. Масловський та ін. Збірник наукових прачь Харківського національного університету Повітряних Сил Украӥни. 2018. № 2 (56). C. 28-39.

Семененко О.М. д-р. воен. наук, ст. науч. сотр. ${ }^{1}$;

Васюхно С. I. ${ }^{2}$; Бокий В. Г. ${ }^{3}$; Бутенко Н. Ф. ${ }^{2}$

1 - Центральный научно-исследовательский институт Вооружённых Сил Украины, Киев;

2 - Центр военно-стратегических исследований Национального университета обороны Украины имени Ивана Черняховского, Киев;

3 - Генеральный штаб Вооружённых Сил Украины

Методический подход к прогнозированию динамики развития Вооружённых Сил Украины с учётом достаточности и эффективности освоения выделенных финансовых ресурсов

Резюме. Одной из важных проблем современного военного строительства есть верность и корректность прогнозирования развития Вооружённых Сил Украины. В статье рассматриваются вопросы повышения эффективности прогнозирования развития Вооружённых Сил Украины и обоснованности формирования потребностей Вооружённых Сил (в вопросах части государственного бюджета Украины в их интересах) путём учёта во время прогнозирования показателей достаточности финансирования и эффективности освоения выделенных финансовых ресурсов.

Ключевые слова: военное строительство; система; прогнозирование; достаточность финансирования; эффективность освоения денег; потребность в финансовых ресурсах; уровень инфляции; оценка уровня развития Вооружённых Сил.

\section{O. Semenenko, DsM, senior researcher ${ }^{1}$;}

S. Vasuhno ${ }^{2}$; V. Boky ${ }^{3}$; N. Butenko ${ }^{2}$

1 - Central Research Institute of the Armed Forces of Ukraine, Kiev;

${ }^{2}$ - Center for Military and Strategic Studies of the National Defence University of Ukraine named after Ivan Cherniakhovskyi, Kyiv;

${ }^{3}$ - General Staff of the Armed Forces of Ukraine

Methodical approach to forecasting the dynamics of development of the Armed Forces of Ukraine taking into account the sufficiency and efficiency of development of allocated financial resources

Resume. One of the important problems of modern military construction is the fidelity and correctness of forecasting the development of the Armed Forces of Ukraine. The article deals with the issues of increasing the effectiveness of forecasting the development of the Armed Forces of Ukraine and the substantiation of the formation of needs for the share of the state budget of Ukraine in the interests of the Armed Forces by taking into account when forecasting the adequacy of their financial support and the efficiency of the development of allocated financial resources.

Keywords: Military construction; system; forecasting; the sufficiency of financing; the efficiency of the development of money; the need for financial resources; the level of inflation; an assessment of the level of development of the Armed Forces. 